\title{
Physical activity and bone: The importance of the various mechanical stimuli for bone mineral density. A review
}

\author{
Bente Morseth $^{1}$, Nina Emaus ${ }^{2}$ and Lone Jørgensen ${ }^{1,2,3}$ \\ 1) Department of Community Medicine, University of Tromsø, Tromsø, Norway \\ 2) Department of Health and Care Sciences, University of Tromsø, Tromsø, Norway \\ 3) Department of Clinical Therapeutic Services, University Hospital North Norway, Tromsø, Norway \\ Correspondence: Bente Morseth, Department of Community Medicine, Faculty of Medicine, University of Tromsø, NO-9037 Tromsø, Norway \\ E-mail: bente.morseth@uit.no Telephone+47 776448 16, direct line+47 77623124 Telefax +47 77644831
}

\begin{abstract}
Numerous studies have reported benefits of regular physical activity on bone mineral density (BMD). The effects of physical activity on BMD are primarily linked to the mechanisms of mechanical loading, but the understanding of the precise mechanism behind the association is incomplete. The aim of this paper was to review the main findings concerning sources and types of mechanical stimuli in relation to BMD. Mechanical forces that act on bone are generated from impact with the ground (ground-reaction forces) and from skeletal muscle contractions (muscle forces or muscle-joint forces), but the relative importance of these two sources has not been elucidated. Both muscle-joint forces and gravitational forces seem to be able to induce bone adaptation independently, and there may be differences in the importance of loading sources at different skeletal sites. The nature of the stimuli is affected by the type, intensity, frequency, and duration of the activity. The activity should be dynamic, not static, and the magnitude and rate of the stimuli should be high. In accordance with this, cross-sectional studies report highest BMD in athletes of high-impact activities such as dancing, soccer, volleyball, basketball, squash, speed skating, gymnastics, hockey, and step-aerobics. Endurance activities such as orienteering, skiing, and triathlon seem to be beneficial to a lesser degree, whereas low-impact activities such as swimming and cycling are associated with lower BMD than controls. Both the intensity and frequency of the activity should be varied and increased beyond the habitual level. Duration of the activity seems to be less important, and a few loading cycles seem to be sufficient.
\end{abstract}

\section{INTRODUCTION}

Osteoporotic fractures constitute a substantial health problem, particularly in the elderly, causing more disability than most other diseases [1]. Among many risk factors, physical inactivity has been related to a higher risk of osteoporotic fracture [2]. Physical activity may postpone the age-related decline in bone mineral density (BMD), and by that reduce the risk of fracture. $\mathrm{BMD}$ is at present the most common single measure of bone strength [3] and also a major predictor of fracture risk [4-7]. The effects of physical activity on BMD are primarily linked to the mechanisms of mechanical loading [8-10]. Knowledge about the importance of various types and sources of loading stimuli will have implications for the design of physical activity programs aimed at preventing osteoporosis.

The aim of this paper was to review the literature concerning mechanical loading in relation to BMD, with focus on which types of stimuli and sources of loading that are most effective.

\section{BONE REMODELING AND MECHANICAL LOADING}

Bone is a highly dynamic tissue that adapts its mass and architecture to the physiological and mechanical environment [11]. Bone is constantly renewed during adulthood, when bone mass and architecture are maintained by bone remodeling [12]. Remodeling involves bone resorption and bone formation, a continuous process of bone cells removing and replacing bone tissue, and an imbalance in the remodeling process can cause osteoporosis. The bone cells involved in remodeling are osteoclasts (which remove bone) and osteoblasts (which produce new bone), forming the "basic multicellular unit" [12]. Remodeling can occur at four surfaces; the periosteal, endocortical, trabecular, and intracortical (Haversian) [12], although the turnover is higher in trabecular than in cortical bone.

As early as in 1892, Wolff stated that bone tissue accommodates to stress that is imposed on it [13], and later research on the topic has been founded on this contention. Several theories have been proposed to explain the loading mechanism, and one of the most recognized is the "Mechanostat theory" by Harold Frost [14-16]. Frost proposed that local deformation from mechanical loading stimulates bone cells, resulting in bone adaptation, under the influence of parameters such as age, sex, environment, genes, nutrition, and systemic biochemical factors [11,17]. Today, it is generally acknowledged that loads applied to bone affect bone mass [9] and morphology (e.g. cross-sectional area and thickness of cortical bone) $[18,19]$ through a mechanism called "mechanotransduction". Mechano- 
transduction involves conversion of a mechanical force into a cellular response. The process is not yet fully understood, but seems to include osteocytes, which detect mechanical strain and transduce the applied strain to the cells (osteoblasts and osteoclasts) on the surface, where bone remodeling (formation and resorption) occurs $[8,10,20]$. Details of the cellular processes of mechanical loading have been reviewed previously [20-22] and will not be further elaborated here.

\section{Physical ACTIVITy ANd BMD}

Data from numerous cross-sectional studies demonstrate a positive association between BMD and physical activity [23-25]. Generally, athletes have higher BMD than age-matched sedentary controls [26-30]. The most extensive evidence from human studies supporting the effect of exercise on bone mass has been obtained from studies of unilateral loading, as in tennis players, where the dominant arm has thicker cortices and up to $22 \%$ higher BMD than the non-dominant arm [31-34].

Intervention studies in pre- and peripubertal children confirm the findings from cross-sectional studies that high-impact physical activity [35-37] and regular physical activity increases BMD $[38,39]$. In adults, the effect of physical activity is smaller and less consistent. Findings from intervention studies in premenopausal women indicate that young women who exercise continue to increase bone mass compared to nonexercising controls [40-42]. In postmenopausal women, systematic reviews indicate that physical activity may slow the rate of bone loss on weight-bearing sites with an effect of approximately $1 \%$ per year $[40,41]$. This finding has been confirmed in two other reviews, which concluded that there is strong evidence of the effect of daily walking on the femoral neck bone mass in postmenopausal women $[43,44]$. The results seen in women are also present in the few existing studies in men [45-47].

Taken together, most results indicate that physical activity has an effect on BMD. Nevertheless, the exact type and amount of physical activity that may increase BMD and reduce the risk of fracture is still uncertain due to lack of randomized, controlled studies (particularly on fracture risk), a large number of confounders to control for, as well as an incomplete understanding of the precise mechanism behind the association between physical activity and BMD $[48,49]$.

\section{WHICH TYPES OF STRAIN ARE MOST EFFECTIVE TO INCREASE BMD?}

A load that is applied to bone is called stress, defined as force divided by area [50]. The applied load causes a mechanical deformation of bone tissue, and this deformation can be measured as strain [11,51]. Strain is the ratio of the amount of shortening $(\Delta \mathrm{l})$ divided by the original length (1), typically expressed as micro- strain, $10^{-6}$ (i.e. a bone of length $500 \mathrm{~mm}$ experiencing $0.5 \mathrm{~mm}$ deformation gives a strain of 0.001 or $0.1 \%$, equal to 1000 microstrain) $[11,20,51]$. Strains may be compressive, tensile (when the bone is stretched), or torsional (shear) (when the bone is twisted), and in most situations, they affect bone in a combined way $[11,50]$, i.e. a deformation can create 2500 microstrain in compression on the concave side of a bending diaphysis, while creating 2000 microstrain in tension on the other side [51].

In humans, an in vivo study of the tibia has shown that running produced larger strains and higher strain rate on the tibia than walking, while bicycling produced lower strains than walking [52]. Step and leg press did not induce larger strain or strain rate than walking. Strain magnitude ranged from 271 to 5027 microstrain and strain rate from 1258 to 38164 microstrain/s. In accordance with these findings, Burr et al. [53] showed that strains during running were 2-3 times higher than during walking.

Frost's mechanostat theory [54] indicates that there is a lower and an upper strain threshold, creating a range where strain stimuli maintains homeostasis of the remodeling process and bone mass, called the physiological loading zone. Below the lower threshold (200 microstrain), called the "minimum effective strain for remodeling", the stimuli is insufficient to maintain formation, and resorption will be the overriding process, resulting in bone loss. Above the upper threshold (2000 microstrain), the "minimum effective strain for modeling", formation is dominant, resulting in bone gain. These thresholds may be relative to the individual's habitual loads [11].

The mechanostat theory mainly relies on the magnitude of the strain [51], and animal studies support that strain magnitude is an important driving force for bone remodeling $[55,56]$. However, several animal studies have demonstrated that dynamic, but not static strains (strain rate $=0$ ), induce bone formation [56-59]. In the animal studies, jumping was more osteogenic than running, and strain rate was higher in jumping than running at similar strain magnitude $[60,61]$. Translated to humans, this would imply that high-impact activities are more effective than running and walking [62]. Moreover, studies of the effect of low-magnitude, high-frequent vibrations indicate that the magnitude may be less important than strain rate and frequency $[48,51,58,59]$. An important implication of this is that an increase in rate or frequency, not only magnitude, may represent overload and bone formation [11,51].

Uneven distribution of the strain seems to have a higher potential for increasing osteogenesis than the habitual loading pattern [62-65], indicating that the intensity and type of activity should be increased or changed beyond the habitual level. Moreover, after a few loading cycles, the adaptive response decreases $[56,66]$. Inserting a rest period after each loading cycle can increase the osteogenic response $[55,58,67,68]$.

In conclusion, animal studies and a small number of 
studies of humans indicate that the stimuli from highimpact activities (e.g., jumping) is more effective than running and walking, as jumping has a higher strain rate than running even at the same strain magnitude. The activity should be dynamic, not static, and the load should be increased or changed beyond the habitual level. Moreover, a few loading cycles seems sufficient, and a rest period after each loading cycle can increase the osteogenic response.

\section{WHICH SOURCES OF MECHANICAL LOADING ARE MOST IMPORTANT TO BMD?}

During physical activity, mechanical forces that act on bone are generated mainly from two sources; loads from impact with the ground (ground-reaction forces) and loads from skeletal muscle contractions (muscle forces or muscle-joint forces) [69,70]. Ground-reaction forces are generated from contact between the body and a surface due to gravitation, whereas muscle loads result from muscle contractions creating a force that is transmitted to the bone through the tendons [49]. The relative importance of these two sources for stimulation of bone is under debate and was recently the center of attention in four symposium reviews $[48,49,69,71]$.

In support of his mechanostat theory, Frost asserted that "Bone strength and mass normally adapt to the largest voluntary loads on bones. The loads come from muscles, not body weight' [48]. From a theoretical view, the magnitude of muscle loading on bone is larger than the gravitational loading, at least during simple static movements, because of differences in lever arm length [48,49]. In a static exercise, groundreaction forces $x$ lever $A$ should equal muscle force $x$ lever $B$ to maintain equilibrium at the joint. Thus, if lever $\mathrm{A}$ is longer than lever $\mathrm{B}$, the muscle forces must be equally larger than ground-reaction forces [49]. However, many factors must be considered in more complex, dynamic exercises; varying lever arm lengths, body mass, acceleration (or deceleration), and eccentric muscle contractions [49]. Thus, only simple loading situations are easily measurable because most movements are complex [49]. Experimental research has shown that peak ground-reaction forces are approximately 1.5 times body weight during walking (3.6-10.8 $\mathrm{km} / \mathrm{h})$ and 2-3 times body weight during running $(5.4-21 \mathrm{~km} / \mathrm{h})$ [72], whereas peak muscle force is 2.8-4.8 times body weight during walking $(1-5 \mathrm{~km} / \mathrm{h})$ and $5-6$ times body weight during jogging and stair walking [73]. For more complex activities, less experimental evidence exists, and the discussion must be based on research of associations between disuse, loading, muscle mass, and bone mass.

Space flight studies are particularly suitable because astronauts are subject to weightlessness, while at the same time, they are required to perform exercise while being in space [49]. During long-duration spaceflight, severe loss of both trabecular and cortical bone mass has been observed, particularly in the lower skeleton, despite daily exercise routines [74-76]. In paraplegic patients, bone loss continues several years longer than muscle loss [77]. These findings indicate that gravitational loading is essential for bone homeostasis $[49,78]$.

Papers in the field of mechanical loading during exercise often refer to weight-bearing and weightsupported (non-weight-bearing) activities. Kohrt et al. [69] has suggested that the terms "impact" (groundreaction forces) and "no-impact" (joint-reaction forces or muscle-joint forces) activities are better suitable to describe the source of loading.

Impact activities generate gravitational loads on the skeleton; thus, impact activities are weight-bearing (e.g. jumping) [69]. However, most impact activities also involve muscle forces $[49,69]$, and the individual effect of the ground-reaction forces can be difficult to separate. Impact activities primarily involve the lower skeleton and are often divided into high-impact and low-impact activities.

In contrast, no-impact activities influence bone mostly through muscle loading [49,69]. No-impact activities can be weight-bearing (e.g. weight lifting) or weight-supported (e.g. swimming, cycling) [49,69].

The understanding of the effects and importance of various strains and loading sources in humans is challenging, and much of the knowledge comes from exercise studies [49]. To differentiate between sources of reaction force, it may be useful to study whether the activity involves primarily impact/ground-reaction loads or not.

Cross-sectional studies have typically compared athletes in various sports and sedentary controls [28,29,63,79-83]. As an example, Nikander et al. [29] compared femoral neck BMD in premenopausal female athletes who competed in sports with different types of load. Athletes competing in high-impact sports (volleyball, hurdling, squash-playing, soccer, speed skating, step-aerobics ) had the highest femoral neck BMD, followed by weight-lifters, thereafter orienteering and skiing athletes, while swimmers and cyclists had BMD similar to the non-athletes [29].

Mudd et al. [79] found that swimmers and runners had lower total and site-specific BMD than athletes in sports such as gymnastics, track, soccer, softball and field hockey. In another study, female runners had highest femoral neck BMD, compared to triathletes and cyclists, who had higher BMD than controls, while swimmers had lower BMD than controls [80]. Similar results have been found in other cross-sectional studies of athletes, mostly premenopausal women [63,81-83] and men [28] with impact activities including soccer, dancing, volleyball, basketball, squash, speed skating, weight lifting, and gymnastics compared to swimming as no-impact activity and/or sedentary controls.

In conclusion, cross-sectional studies indicate that a range of high-impact activities are associated with higher BMD, while swimming and cycling are associated with lower BMD, than controls. Endurance activities seem to be beneficial to a lesser degree. These studies indicate that ground-reaction forces are impor- 
tant for site-specific BMD and that muscle contractions are less important but still effective. However, causal conclusions cannot be drawn from cross-sectional studies.

In an intervention study, Kohrt et al. [73] compared the effect of impact load (walking, jogging, stair climbing) and no-impact, weight-bearing load (weightlifting, rowing) on BMD in postmenopausal women. After 9 months, both types of exercise increased spine and total hip BMD, while only the impact group increased their femoral neck BMD [73]. Impact activities (walking, jogging, star climbing) were associated with the highest increase in BMD, in contrast to controls who did not increase their BMD at all [73]. Likewise, Snow-Harter et al. [42] found that in young women, both weight-training and running produced an increase in spine BMD, whereas only weight-training increased muscle strength. Intervention studies indicate that gravitational forces are essential for BMD of the femoral neck, but not the spine, suggesting that muscle contractions and ground-reaction forces could be efficient at different skeletal sites. However, in other studies, no-impact resistance training have been found to increase or preserve femoral neck BMD in postmenopausal women [84] and elderly men [85], emphasizing the inconsistency of the findings.

Unfortunately, most studies of humans are based on small sample sizes, and epidemiological studies of large cohorts are difficult to implement. Recent metaanalyses by Martyn-St James and Carroll [86-90] studied the effect of different exercise types on BMD in pre- and postmenopausal women. Resistance training alone increased lumbar spine BMD, but not fe- moral neck BMD $[86,87,89]$, whereas combining impact activities with resistance training significantly increased BMD at both sites [89,90]. In postmenopausal women, low-impact exercise (jogging combined with stair climbing and walking) also increased BMD at the lumbar spine and femoral neck [90], but not walking alone [88]. These meta-analyses suggest that impact forces of a certain magnitude and rate, but not resistance training, were sufficient to increase femoral neck BMD, and that resistance training has strongest effect on lumbar spine BMD.

\section{CONCLUSION}

The existing literature shows that both muscle-joint forces and gravitational forces may be able to induce bone adaptation independently; though in most situations these forces act together. Ground-reaction forces of a certain magnitude and rate seem to be essential for BMD at the hip, but not the spine, whereas resistance training seems to have strongest effect on spine BMD. This suggests that muscle contractions and groundreaction forces could act differently at different skeletal sites. The nature of the activity should be dynamic, not static, and the magnitude and rate of the stimuli should be high, preferentially involving highimpact activities and resistance training. Endurance activities seem to be beneficial to a lesser degree, whereas low-impact activities are not beneficial. Both the intensity and frequency of the activity should be varied and increased beyond the habitual level. Duration of the activity seems to be less important, as a few loading cycles seem to be sufficient.

\section{REFERENCES}

1. Johnell O, Kanis JA. An estimate of the worldwide prevalence and disability associated with osteoporotic fractures. Osteoporos Int 2006; 17 (12): 1726-1733.

2. Moayyeri A. The association between physical activity and osteoporotic fractures: a review of the evidence and implications for future research. Ann Epidemiol 2008; 18 (11): 827-835.

3. Ammann P, Rizzoli R. Bone strength and its determinants. Osteoporos Int 2003; 14 (Suppl 3): S13-18.

4. Kanis JA, Borgstrom F, De Laet C, Johansson H, Johnell O, Jonsson B, Oden A, Zethraeus N, Pfleger B, Khaltaev N. Assessment of fracture risk. Osteoporos Int 2005; 16 (6): 581-589.

5. Turner $\mathrm{CH}$. Biomechanics of bone: determinants of skeletal fragility and bone quality. Osteoporos Int 2002; 13 (2): $97-104$.

6. Johnell O, Kanis JA, Oden A, Johansson H, De Laet C, Delmas P, Eisman JA, Fujiwara S, Kroger H, Mellstrom D, Meunier PJ, Melton LJ, 3rd, O'Neill T, Pols H, Reeve J, Silman A, Tenenhouse A. Predictive value of BMD for hip and other fractures. J Bone Miner Res 2005; 20 (7): 1185-1194.

7. Marshall D, Johnell O, Wedel H. Meta-analysis of how well measures of bone mineral density predict occurrence of osteoporotic fractures. BMJ 1996; 312 (7041): 1254-1259.

8. Shipp KM. Exercise for people with osteoporosis: translating the science into clinical practice. Curr Osteoporos Rep 2006; 4 (4): 129-133.

9. Suva LJ, Gaddy D, Perrien DS, Thomas RL, Findlay DM. Regulation of bone mass by mechanical loading: microarchitecture and genetics. Curr Osteoporos Rep 2005; 3 (2): 46-51.

10. Zernicke R, MacKay C, Lorincz C. Mechanisms of bone remodeling during weight-bearing exercise. Appl Physiol Nutr Metab 2006; 31 (6): 655-660.

11. Skerry TM. The response of bone to mechanical loading and disuse: fundamental principles and influences on osteoblast/ osteocyte homeostasis. Arch Biochem Biophys 2008; 473 (2): 117-123.

12. Robling AG, Castillo AB, Turner CH. Biomechanical and molecular regulation of bone remodeling. Annu Rev Biomed Eng 2006; 8: 455-498.

13. Frost HM. From Wolff's law to the mechanostat: a new "face" of physiology. J Orthop Sci 1998; 3 (5): 282-286.

14. Frost HM. Bone's mechanostat: a 2003 update. Anat Rec A Discov Mol Cell Evol Biol 2003; 275 (2): 1081-1101.

15. Frost HM. Bone "mass" and the "mechanostat": a proposal. Anat Rec 1987; 219 (1): 1-9. 
16. Frost HM. The mechanostat: a proposed pathogenic mechanism of osteoporoses and the bone mass effects of mechanical and nonmechanical agents. Bone Miner 1987; 2 (2): 73-85.

17. Skerry TM. One mechanostat or many? Modifications of the site-specific response of bone to mechanical loading by nature and nurture. J Musculoskelet Neuronal Interact 2006; 6 (2): 122-127.

18. Turner CH, Robling AG. Designing exercise regimens to increase bone strength. Exerc Sport Sci Rev 2003; 31 (1): $45-50$.

19. Seeman E. An exercise in geometry. J Bone Miner Res 2002; 17 (3): 373-380.

20. Turner CH, Pavalko FM. Mechanotransduction and functional response of the skeleton to physical stress: the mechanisms and mechanics of bone adaptation. J Orthop Sci 1998; 3 (6): 346-355.

21. Klein-Nulend J, Bacabac RG, Mullender MG. Mechanobiology of bone tissue. Pathol Biol (Paris) 2005; 53 (10): $576-580$.

22. Scott A, Khan KM, Duronio V, Hart DA. Mechanotransduction in human bone: in vitro cellular physiology that underpins bone changes with exercise. Sports Med 2008; 38 (2): 139-160.

23. Barry DW, Kohrt WM. Exercise and the preservation of bone health. J Cardiopulm Rehabil Prev 2008; 28 (3): $153-162$.

24. Beck BR, Snow CM. Bone health across the lifespan - exercising our options. Exerc Sport Sci Rev 2003; 31 (3): 117-122.

25. Kohrt WM, Bloomfield SA, Little KD, Nelson ME, Yingling VR, American College of Sports Medicine. American College of Sports Medicine Position Stand: physical activity and bone health. Med Sci Sports Exerc 2004; 36 (11): 1985-1996.

26. Suominen H. Bone mineral density and long term exercise. An overview of cross-sectional athlete studies. Sports Med 1993; 16 (5): $316-330$.

27. Karlsson MK, Johnell O, Obrant KJ. Bone mineral density in professional ballet dancers. Bone Miner 1993; 21 (3): $163-169$.

28. Karlsson MK, Johnell O, Obrant KJ. Bone mineral density in weight lifters. Calcif Tissue Int 1993; 52 (3): 212-215.

29. Nikander R, Sievanen H, Heinonen A, Kannus P. Femoral neck structure in adult female athletes subjected to different loading modalities. J Bone Miner Res 2005; 20 (3): 520-528.

30. Karlsson MK, Hasserius R, Obrant KJ. Bone mineral density in athletes during and after career: a comparison between loaded and unloaded skeletal regions. Calcif Tissue Int 1996; 59 (4): 245-248.

31. Huddleston AL, Rockwell D, Kulund DN, Harrison RB. Bone mass in lifetime tennis athletes. JAMA 1980; 244 (10): $1107-$ 1109.

32. Jones HH, Priest JD, Hayes WC, Tichenor CC, Nagel DA. Humeral hypertrophy in response to exercise. J Bone Joint Surg Am 1977; 59 (2): 204-208.

33. Haapasalo H, Sievanen H, Kannus P, Heinonen A, Oja P, Vuori I. Dimensions and estimated mechanical characteristics of the humerus after long-term tennis loading. J Bone Miner Res 1996; 11 (6): 864-872.

34. Bass SL, Saxon L, Daly RM, Turner CH, Robling AG, Seeman E, Stuckey S. The effect of mechanical loading on the size and shape of bone in pre-, peri-, and postpubertal girls: a study in tennis players. J Bone Miner Res 2002; 17 (12): $2274-2280$.

35. Nurmi-Lawton JA, Baxter-Jones AD, Mirwald RL, Bishop JA, Taylor P, Cooper C, New SA. Evidence of sustained skeletal benefits from impact-loading exercise in young females: a 3-year longitudinal study. J Bone Miner Res 2004; 19 (2): 314 322.

36. French SA, Fulkerson JA, Story M. Increasing weight-bearing physical activity and calcium intake for bone mass growth in children and adolescents: a review of intervention trials. Prev Med 2000; 31 (6): 722-731.

37. MacKelvie KJ, Khan KM, Petit MA, Janssen PA, McKay HA. A school-based exercise intervention elicits substantial bone health benefits: a 2-year randomized controlled trial in girls. Pediatrics 2003; 112 (6 Pt 1): e447.

38. Linden C, Ahlborg HG, Besjakov J, Gardsell P, Karlsson MK. A school curriculum-based exercise program increases bone mineral accrual and bone size in prepubertal girls: two-year data from the pediatric osteoporosis prevention (POP) study. $J$ Bone Miner Res 2006; 21 (6): 829-835.

39. Gunter K, Baxter-Jones AD, Mirwald RL, Almstedt H, Fuller A, Durski S, Snow C. Jump starting skeletal health: a 4-year longitudinal study assessing the effects of jumping on skeletal development in pre and circum pubertal children. Bone 2008; 42 (4): 710-718.

40. Wallace BA, Cumming RG. Systematic review of randomized trials of the effect of exercise on bone mass in pre- and postmenopausal women. Calcif Tissue Int 2000; 67 (1): 10-18.

41. Wolff I, van Croonenborg JJ, Kemper HC, Kostense PJ, Twisk JW. The effect of exercise training programs on bone mass: a meta-analysis of published controlled trials in pre- and postmenopausal women. Osteoporos Int 1999; 9 (1): 1-12.

42. Snow-Harter C, Bouxsein ML, Lewis BT, Carter DR, Marcus R. Effects of resistance and endurance exercise on bone mineral status of young women: a randomized exercise intervention trial. J Bone Miner Res 1992; 7 (7): 761-769.

43. Bonaiuti D, Shea B, Iovine R, Negrini S, Robinson V, Kemper HC, Wells G, Tugwell P, Cranney A. Exercise for preventing and treating osteoporosis in postmenopausal women. Cochrane Database Syst Rev 2002 (3): CD000333.

44. Shea B, Bonaiuti D, Iovine R, Negrini S, Robinson V, Kemper HC, Wells G, Tugwell P, Cranney A. Cochrane Review on exercise for preventing and treating osteoporosis in postmenopausal women. Eura Medicophys 2004; 40 (3): 199-209.

45. Kelley GA, Kelley KS, Tran ZV. Exercise and bone mineral density in men: a meta-analysis. J Appl Physiol 2000; 88 (5): 1730-1736.

46. Mussolino ME, Looker AC, Orwoll ES. Jogging and bone mineral density in men: results from NHANES III. Am J Public Health 2001; 91 (7): 1056-1059.

47. Gardner MM, Robertson MC, Campbell AJ. Exercise in preventing falls and fall related injuries in older people: a review of randomised controlled trials. Br J Sports Med 2000; 34 (1): 7-17.

48. Beck BR. Muscle forces or gravity - what predominates mechanical loading on bone? Introduction. Med Sci Sports Exerc 2009; 41 (11): 2033-2036.

49. Judex S, Carlson KJ. Is bone's response to mechanical signals dominated by gravitational loading? Med Sci Sports Exerc 2009; 41: 2037-2043.

50. Turner CH, Burr DB. Basic biomechanical measurements of bone: a tutorial. Bone 1993; 14 (4): 595-608.

51. Judex S, Gupta S, Rubin C. Regulation of mechanical signals in bone. Orthod Craniofac Res 2009; 12 (2): 94-104.

52. Milgrom C, Finestone A, Simkin A, Ekenman I, Mendelson S, Millgram M, Nyska M, Larsson E, Burr D. In-vivo strain measurements to evaluate the strengthening potential of exercises on the tibial bone. J Bone Joint Surg B 2000; 82 (4): 591-594. 
53. Burr DB, Milgrom C, Fyhrie D, Forwood M, Nyska M, Finestone A, Hoshaw S, Saiag E, Simkin A. In vivo measurement of human tibial strains during vigorous activity. Bone 1996; 18 (5): 405-410.

54. Lindén C. Physical activity and its effect on bone in the short- and long-term perspective. Malmö: Department of Orthopaedics, Malmö University Hospital, Lund University; 2006.

55. Rubin CT, Lanyon LE. Regulation of bone mass by mechanical strain magnitude. Calcif Tissue Int 1985; 37 (4): $411-417$.

56. Rubin CT, Lanyon LE. Regulation of bone formation by applied dynamic loads. J Bone Joint Surg Am 1984; 66 (3): $397-402$.

57. Lanyon LE, Rubin CT. Static vs dynamic loads as an influence on bone remodelling. J Biomech 1984; 17 (12): 897-905.

58. O'Connor JA, Lanyon LE, MacFie H. The influence of strain rate on adaptive bone remodelling. J Biomech 1982; 15 (10): 767-781.

59. Turner CH, Owan I, Takano Y. Mechanotransduction in bone: role of strain rate. Am J Physiol 1995; 269 (3 Pt 1): E438-442.

60. Judex S, Zernicke RF. High-impact exercise and growing bone: relation between high strain rates and enhanced bone formation. J Appl Physiol 2000; 88 (6): 2183-2191.

61. Judex S, Zernicke RF. Does the mechanical milieu associated with high-speed running lead to adaptive changes in diaphyseal growing bone? Bone 2000; 26 (2): 153-159.

62. Judex S, Rubin C. Mechanical influences on bone mass and morphology. In: Adler RA, editor. Osteoporosis: Humana Press; 2010: 181-205.

63. Fehling PC, Alekel L, Clasey J, Rector A, Stillman RJ. A comparison of bone mineral densities among female athletes in impact loading and active loading sports. Bone 1995; 17 (3): 205-210.

64. Lanyon LE. Functional strain as a determinant for bone remodeling. Calcif Tissue Int 1984; 36 (Suppl 1): S56-61.

65. Lanyon LE. Using functional loading to influence bone mass and architecture: objectives, mechanisms, and relationship with estrogen of the mechanically adaptive process in bone. Bone 1996; 18 (1 Suppl): 37S-43S.

66. Umemura Y, Ishiko T, Yamauchi T, Kurono M, Mashiko S. Five jumps per day increase bone mass and breaking force in rats. J Bone Miner Res 1997; 12 (9): 1480-1485.

67. Robling AG, Hinant FM, Burr DB, Turner CH. Improved bone structure and strength after long-term mechanical loading is greatest if loading is separated into short bouts. J Bone Miner Res 2002; 17 (8): 1545-1554.

68. Lanyon LE. Control of bone architecture by functional load bearing. J Bone Miner Res 1992; 7 (Supp1 2): S369-375.

69. Kohrt WM, Barry DW, Schwartz RS. Muscle forces or gravity: What predominates mechanical loading on bone? Med Sci Sports Exerc 2009; 41 (11): 2050-2055.

70. Turner CH. Homeostatic control of bone structure: an application of feedback theory. Bone 1991; 12 (3): $203-217$.

71. Robling AG. Is bone's response to mechanical signals dominated by muscle forces? Med Sci Sports Exerc 2009; 41: 20442049.

72. Nilsson J, Thorstensson A. Ground reaction forces at different speeds of human walking and running. Acta Physiol Scand 1989; 136 (2): 217-227.

73. Kohrt WM, Ehsani AA, Birge SJ, Jr. Effects of exercise involving predominantly either joint-reaction or ground-reaction forces on bone mineral density in older women. J Bone Miner Res 1997; 12 (8): 1253-1261.

74. Lang TF. What do we know about fracture risk in long-duration spaceflight? J Musculoskelet Neuronal Interact 2006; 6 (4): 319-321.

75. Keyak JH, Koyama AK, LeBlanc A, Lu Y, Lang TF. Reduction in proximal femoral strength due to long-duration spaceflight. Bone 2009; 44 (3): 449-453.

76. Lang TF, Leblanc AD, Evans HJ, Lu Y. Adaptation of the proximal femur to skeletal reloading after long-duration spaceflight. J Bone Miner Res 2006; 21 (8): 1224-1230.

77. Dionyssiotis Y, Trovas G, Galanos A, Raptou P, Papaioannou N, Papagelopoulos P, Petropoulou K, Lyritis GP. Bone loss and mechanical properties of tibia in spinal cord injured men. J Musculoskelet Neuronal Interact 2007; 7 (1): $62-68$.

78. Lang T, LeBlanc A, Evans H, Lu Y, Genant H, Yu A. Cortical and trabecular bone mineral loss from the spine and hip in long-duration spaceflight. $J$ Bone Miner Res 2004; 19 (6): 1006-1012.

79. Mudd LM, Fornetti W, Pivarnik JM. Bone mineral density in collegiate female athletes: comparisons among sports. $J$ Athl Train 2007; 42 (3): 403-408.

80. Duncan CS, Blimkie CJ, Cowell CT, Burke ST, Briody JN, Howman-Giles R. Bone mineral density in adolescent female athletes: relationship to exercise type and muscle strength. Med Sci Sports Exerc 2002; 34 (2): 286-294.

81. Bennell KL, Malcolm SA, Khan KM, Thomas SA, Reid SJ, Brukner PD, Ebeling PR, Wark JD. Bone mass and bone turnover in power athletes, endurance athletes, and controls: a 12-month longitudinal study. Bone 1997; 20 (5): 477-484.

82. Yung PS, Lai YM, Tung PY, Tsui HT, Wong CK, Hung VW, Qin L. Effects of weight bearing and non-weight bearing exercises on bone properties using calcaneal quantitative ultrasound. Br J Sports Med 2005; 39 (8): 547-551.

83. Heinonen A, Oja P, Kannus P, Sievanen H, Haapasalo H, Manttari A, Vuori I. Bone mineral density in female athletes representing sports with different loading characteristics of the skeleton. Bone 1995; 17 (3): 197-203.

84. Nelson ME, Fiatarone MA, Morganti CM, Trice I, Greenberg RA, Evans WJ. Effects of high-intensity strength training on multiple risk factors for osteoporotic fractures. A randomized controlled trial. JAMA 1994; 272 (24): 1909-1914.

85. Menkes A, Mazel S, Redmond RA, Koffler K, Libanati CR, Gundberg CM, Zizic TM, Hagberg JM, Pratley RE, Hurley BF. Strength training increases regional bone mineral density and bone remodeling in middle-aged and older men. J Appl Physiol 1993; 74 (5): 2478-2484.

86. Martyn-St James M, Carroll S. High-intensity resistance training and postmenopausal bone loss: a meta-analysis. Osteoporos Int 2006; 17 (8): 1225-1240.

87. Martyn-St James M, Carroll S. Progressive high-intensity resistance training and bone mineral density changes among premenopausal women: evidence of discordant site-specific skeletal effects. Sports Med 2006; 36 (8): 683-704.

88. Martyn-St James M, Carroll S. Meta-analysis of walking for preservation of bone mineral density in postmenopausal women. Bone 2008; 43 (3): 521-531.

89. Martyn-St James M, Carroll S. Effects of different impact exercise modalities on bone mineral density in premenopausal women: a meta-analysis. J Bone Miner Metab 2010; 28 (3): 251-267.

90. Martyn-St James M, Carroll S. A meta-analysis of impact exercise on postmenopausal bone loss: the case for mixed loading exercise programmes. Br J Sports Med 2009; 43 (12): 898-908. 